\title{
PEMODELAN DAN REKONSTRUKSI METABOLISME: TINJAUAN DARI PERKEMBANGAN SISTEM BIOLOGI
}

\author{
Maria Yustiningsih \\ Program Studi Pendidikan Biologi, Universitas Timor \\ Email: yustiningsih@gmail.com
}

Citasi: Yustiningsih, M. 2018. Pemodelan dan Rekontruksi Metabolisme: Tinjauan dari Perkembangan Sistem Biologi. Mangifera edu Volume 3 Nomor 1, Juli 2018. Hal 52-61

\begin{abstract}
ABSTRAK
Metabolisme merupakan salah satu proses yang sangat penting pada makhluk hidup. Proses rangkaian reaksi antara substrat, enzim, protein ini berjalan simultan tanpa kesalahan karena diregulasi oleh DNA pada setiap level gen (genomic) dan dapat menghasilkan ekspresi gen berbeda yang dipengaruhi oleh proses penterjemahan RNA (transkriptomic) dari nucleus; namun demikian proses ini belum menentukan nasib dan arah produk (ekspresi) gen yang dihasilkan (proteomic). Interaksi proteomic dalam membangun suatu network yang saling berhubungan dan berjalan simultan belum dapat dideskripsikan karena masih terbatasnya pemahaman tentang interaksi antar protein tersebut dan perannya dalam metabolisme (metabolomic). Searah dengan perkembangan sistem biologi, maka proses ini kemudian dikuantifikasi menggunakan pemodelan metabolisme regulatory network (MRN) yang menggabungkan perspektif matematika, kimia dan biologi (genomic). Salah satu contoh MRN adalah rekonstruksi metabolisme E.coli yang melibatkan 95 reaksi, mengkatalisis transformasi 72 metabolit yaitu glikolisis, TCA cycle, jalur penthosa fosfat, jalur secondary pathway glukoneogenesis dan anapleurotic reaction. Keberhasilan identifikasi proses metabolisme yang kompleks pada tiap level ini selanjutnya dapat menghasilkan reaksi yang terkendali dengan hasil hasil yang diinginkan. Pengembangan aplikasi MRN di masa depan dapat digunakan dalam metabolic enginering, penyempurnaan alogaritma ORF enzim dan prediksi evaluasi fenotip organisme.
\end{abstract}

Kata Kunci: Metabolisme, Pemodelan dan Rekontruksi, Sistem biologi,

\section{PENDAHULUAN}

Sistem Biologi (Systems Biology) atau biologi sistem secara umum dapat diartikan sebagai ilmu atau pendekatan yang mempelajari tentang komponen biologi yang dapat berupa molekul, sel, organisme atau spesies, dan interaksi antar komponen-komponen tersebut dalam menyusun sistem kehidupan organisme. Dalam mempelajari perilaku dan dinamika organisme yang kompleks maka digunakan berbagai teknologi pengukuran yang sistematis menggunakan pendekatan omic, bioinformatika, model matematika dan komputasi untuk memprediksi pola interaksi tersebut (Harvard Medical School, 2010). Menurut Nicholson \& Wilson (2003) data-data berupa genomic, transkriptomic, proteomic dan metabolomic dapat diintegrasikan dalam bentuk komputasi sehingga keseluruhan level 
dan konsep biomolekuler dalam suatu organisme dapat dikuantifikasi dan dipahami. Berkhout et al (2012) mengatakan bahwa pengembangan konsep biologi sistem memungkinkan terjawabnya mekanisme sistem fungsional organisme dengan mempelajari pola interaksi seluler. Seiring perkembangannya, biologi sistem kemudian dapat digunakan untuk menjelaskan secara lebih detail tentang berbagai proses dan sistem fungsional yang penting yang terjadi dalam suatu organisme, seperti metabolisme, interaksi antar gene dan signaling (Peter \& Davidson, 2013).

Metabolisme merupakan salah satu proses yang sangat penting yang terjadi pada makhluk hidup; karena dalam proses ini selain terjadi reaksi yang simultan juga terjadi proses penghasilan energi untuk kelangsungan hidup mahkluk hidup (Palsson, 2009). Begitu pentingnya proses ini maka pemahaman tentang metabolism terus dikembangkan baik melalui penelitian maupun dengan berbagai percobaan untuk mendapatkan pemahaman yang lebih terkini dan komprehensif. Konsep dasar tentang metabolisme yang penting terdapat pada rangkaian reaksi yang melibatkan substrat, enzim, protein dan interaksi antara enzim-enzim (Berkhout et al, 2012). Konsep ini benar meskipun lebih bersifat kualitatif dan sulit untuk diukur sehingga belum sesuai dengan era genome scale yang berkembang pesat sejak awal abad kedua puluh. Artinya dalam pemahaman dasar tersebut belum diketahui bagaimana setiap protein saling berinteraksi membentuk network yang kokoh (robustness) dan tidak terjadi kesalahan dalam prosesnya (Wagner, 2012). Seiring dengan perkembangannya kemudian muncul suatu logika bahwa dalam satu reaksi yang kompleks, jika setiap komponennya (input- proses) sudah diketahui maka seharusnya hasilnya dapat diprediksi dan dikuantifikasi (Hefzi et al, 2013).

Pembahasan pada tulisan ini bertujuan untuk mengetahui dan mengkaji perkembangan tentang konsep metabolisme ditinjau dari konsep dasar, penyusunan pemodelan metabolic regulatory network dan rekonstruksi metabolic network serta aplikasi di masa datang. Tulisan ini tidak akan membedakan jenis - jenis metabolism yang terjadi pada makhluk hidup namun hanya akan berfokus pada konsep metabolism secara umum, khususnya jika dihubungkan dengan perkembangan ilmu biologi sistem.

\section{Konsep dasar metabolime}

Metabolisme adalah proses kimia yang terjadi di dalam tubuh makhluk hidup maupun di dalam sel (Kusnadi, 2009). Metabolisme seluler terjadi dikatalisis oleh enzim dan interaksi antar enzim melalui serangkaian reaksi kimia yang terjadi secara spontan. Reaksi 
- reaksi ini selain melibatkan berbagai jenis metabolite juga dapat menghasilkan energi maupun mendaur ulang komponen yang sudah tidak diperlukan oleh tubuh (Hefzi et al, 2013). Proses metabolisme bersifat spesifik dan berjalan simultan tanpa kesalahan karena diregulasi oleh DNA di nukleus dengan hasil ekspresi yang dapat berupa protein di sitoplasma, reticulum endoplasma maupun jenis translokasi protein yang lain. Fenotipe yang terbentuk berasal dari aliran DNA ke RNA menjadi protein melalui proses transkripsi dan translasi (Karp, 2010), yang skemanya dapat dilihat pada gambar 1.

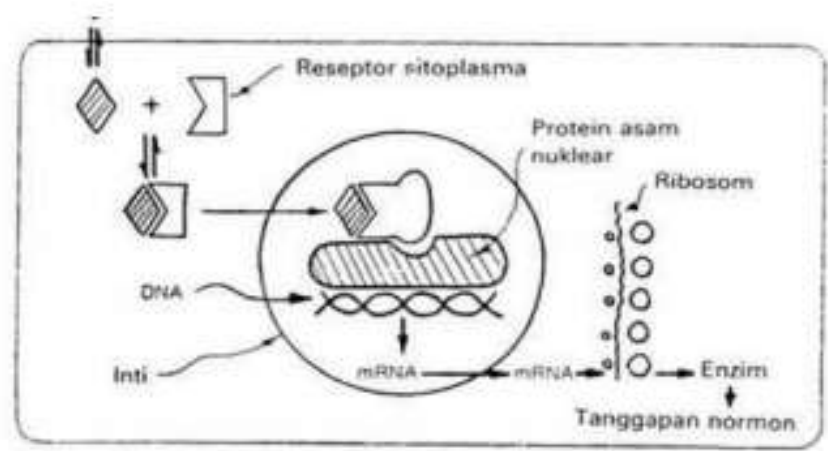

Gambar 1. Overview proses transduksi sinyal - respon seluler (Suarsana, 2009)

Konsep diatas menggambarkan bahwa pada setiap level gen (genomic) dapat menghasilkan ekspresi berbeda yang dipengaruhi oleh proses penterjemahan RNA (transkriptomic) dari nucleus, namun belum menentukan nasib dan arah produk gen yang dihasilkan (proteomic). Interaksi proteomic dalam membangun suatu network yang saling berhubungan dan berjalan simultan belum dapat dideskripsikan karena masih terbatasnya pemahaman tentang interaksi antar protein yang dihasilkan dan perannya dalam metabolisme (Hein et al, 2013).

\section{Perkembangan konsep metabolism}

Hasil pemetaan human genom project membawa dampak signifikan khususnya dalam pemahaman molekuler genomic - proteomic - metabolomic. Setelah berbagai jenis gen dan fungsinya serta ekspresinya diketahui, maka dengan menggunakan database saat ini kita dapat mengetahui berbagai jenis komponen seluler dan pathway dalam metabolisme meskipun belum lengkap seluruhnya (Palsson, 2000). Sejalan dengan perkembangan era genom scale maka pemahaman mengenai metabolisme juga mengalami peningkatan. Metabolisme tidak saja dipahami sebagai proses yang menghasilkan dan menggunakan energi, namun juga merupakan hasil interaksi protein (protein - protein interaction) yang kompleks dan melibatkan enzim kinetic, parameter - parameter kimia, signaling dan network 
yang diregulasi oleh gen (Costa, 2008). Gambar 1 menunjukkan skema networking dan protein - protein interaction yang terjadi pada proses metabolisme.

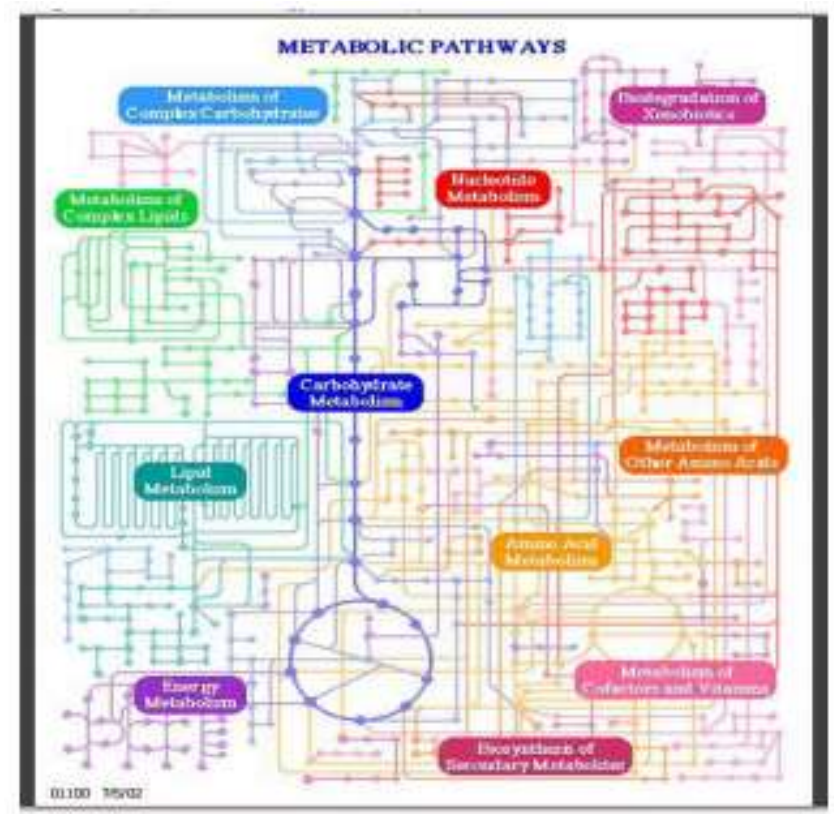

\section{Gambar 1. Interaksi dan networking antar metabolic pathway (www.manet.illinois.edu)}

Networking dan interaksi protein dalam metabolomic dapat dipahami dari berbagai macam perspektif, yaitu perspektif matematika, kimia dan biologi maupun gabungan antara ketiganya. Perspektif matematika digunakan untuk mengkuantifikasi proses metabolisme sehingga proses dan outputnya dapat diprediksi dan dikendalikan. Perspektif kimia menggambarkan metabolisme sebagai proses yang melibatkan interaksi subsrat - enzim dengan input yang dapat diatur secara termodikamika, stoichiometry, dan kinetic. Sementara perspektif biologi mendalami peran genom (genom scale dan expressions) yang diinduksi oleh lingkungan melalui mekanisme signaling (Palsson, 2000). Ketiganya jika digabungkan selain dapat menggambarkan suatu pemodelan proses metabolisme juga dapat digunakan untuk merekonstruksi metabolic network sehingga dapat digunakan untuk memperdalam pemahaman tentang metabolisme dan dapat dikembangkan dalam berbagai macam aplikasi (Berkhout et al, 2012).

\section{Metabolic regulatory network}

Metabolic regulatory network (MRN) adalah salah satu jenis pemodelan yang menggambarkan proses metabolisme seluler yang dipengaruhi oleh interaksi network antara enzim, aliran metabolit (metabolit flux), dan signaling yang keseluruhannya diregulasi oleh 
gen. Model ini juga menggambarkan bagaimana lingkungan dapat mempengaruhi pola interaksi proteomic sehingga dapat berpengaruh pada setiap level sel (Berkhout et al, 2012).

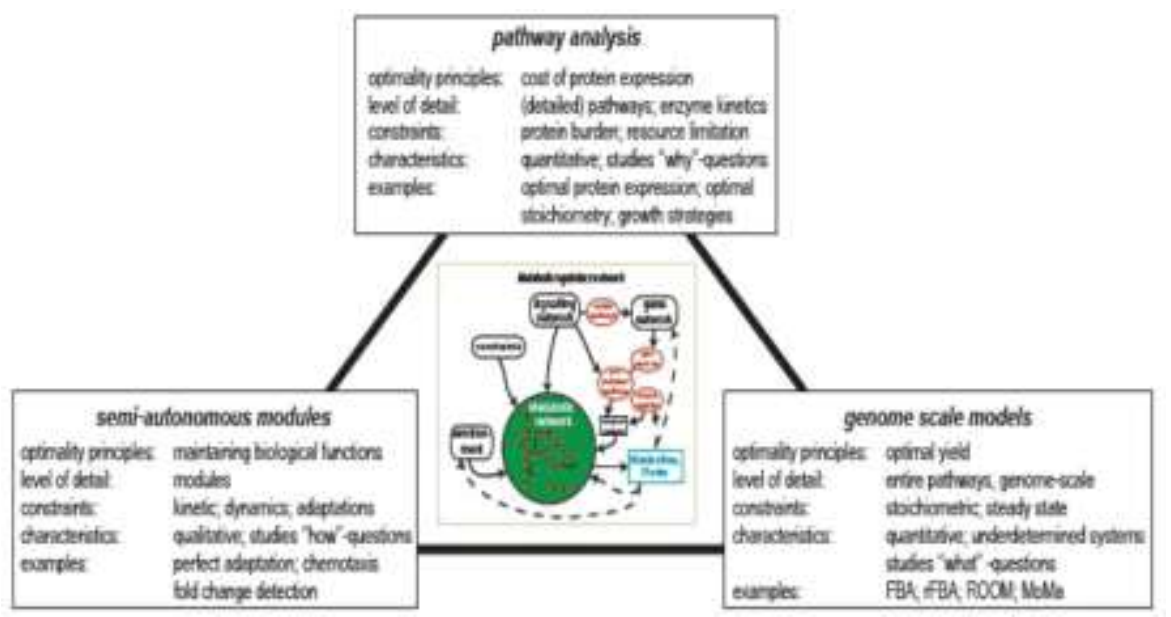

Gambar 2. Overview and level regulatory interaction metabolic regulation network (Berkhout et al, 2012)

Pemodelan MRN menggambarkan bahwa metabolic network dapat dianalisis berdasarkan beberapa pendekatan yaitu jalur pathway analysis, genome scale dan autonomous modules. Jalur pathway analysis mengkaji secara detail reaksi yang dapat mempengaruhi pathway metabolisme. Genome scale menggunakan informasi dari keseluruhan genom yang dapat mempengaruhi aliran / flux distribusi network sehingga dapat berpengaruh pada fenotipe dan tingkah laku organisme. Sedangkan semi autonomous module berfungsi untuk mengetahui control pada keseluruhan network dan mekanisme fungsional pada tingkat molekuler pada organisme (Berkhout et al, 2012).

\section{Rekonstruksi Metabolic Network}

Rekonstruksi metabolic network merupakan rekonstruksi metabolic pada genom scale yang menggabungkan perspektif kimia dan matematika. Secara kimia jika substrat dan enzim yang digunakan telah diketahui maka hasilnya dapat diprediksi. Secara matematika proses ini kemudian dapat dikuantifikasi dan diuji dengan persamaan matematika (Hefzi et al, 2013). Dari ketiga perspektif ini maka metabolisme kemudian dapat direkonstruksi. Hasil protocol standar rekonstruksi telah dipublikasikan Thiele \& Palsson (2010). Salah satu contoh rekonstruksi metabolisme yang pernah dilakukan adalah rekonstruksi metabolism 
pada E.coli yang melibatkan 95 reaksi, mengkatalisis transformasi 72 metabolit yang meliputi glikolisis (Thiele\& Palsson, 2010), TCA cycle, jalur penthosa fosfat dan jalur secondary pathway (glukoneogenesis dan anapleurotic reaction) (Hezfi et al, 2013). Rekonstruksi metabolic network terdiri beberapa tahap yaitu : (1) identifikasi dan anotasi genom berdasarkan database yang dapat diakses pada KEGG dan metaSHARK (2) membuat draft rekonstruksi berdasarkan database (3) melakukan verifikasi dan pengujian draft dengan menggunakan persamaan matematik Bolean dan Graft (4) membuat pemodelan terhadap hasil yang positif untuk verifikasi tingkat akurasinya. Gambar 3 dan gambar 4 menggambarkan rekonstruksi metabolic berdasarkan Thiele\& Palsson (2010).

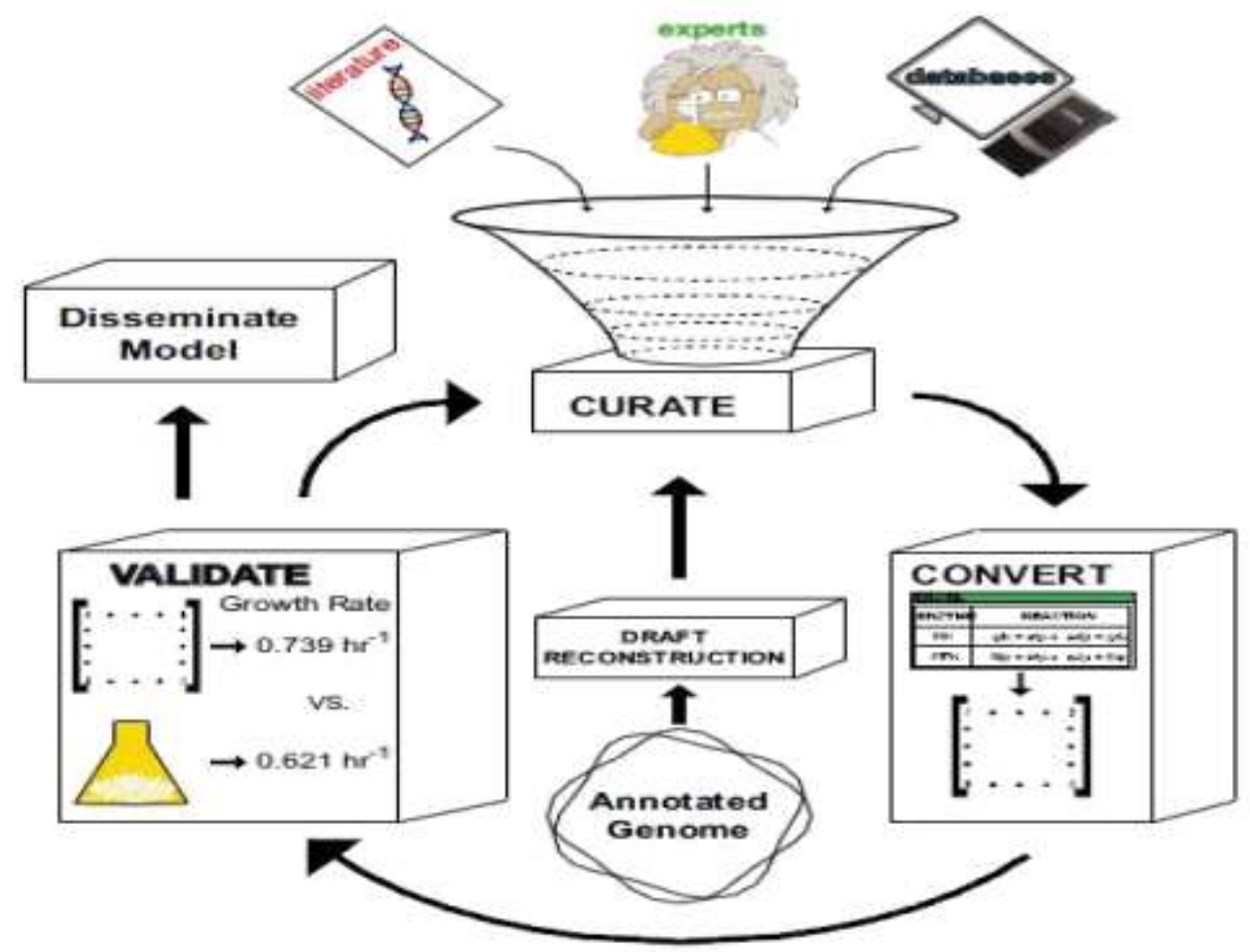

Gambar 3. Overview proses rekonstruksi metabolic network (Hefzi et al, 2013) 


\section{BOX 12.1 A Draft Reconstruction for E. coli's Core Metabolism \\ For E. coli, specific databases such as EcoCyc [21] can be used to obtain a genome annotation. Some examples of the data gathered in this step are presented below in:

$\begin{array}{lllll}\text { Gene alias } & \text { Locus name } & \text { EcoCyc function } & \text { EC number } & \text { Readion } \\ \text { glk } & \text { b2388 } & \text { Clucokinase } & 27.1 .2 & \text { Glucose }+ \text { ATP } \rightarrow \text { Glucose-6-phosphate }+ \text { ADP } \\ \text { pg } & \text { b4025 } & \text { Glucose-6-phosphate lsomerase } & 5.3 .1 .9 & \text { Clucose-6-phosphate } \rightarrow \text { Fructose-6-phosphate }\end{array}$

Information for reactions in glycolysis, the TCA gycle, the pentose phosphate pathway is obtained from the annotation. When this was done for E. colicore metabolism, the reconstruction comprised 53 reactions.

Draft Rekonstruksi metabolisme E.coli (Hefzi et al, 2013)

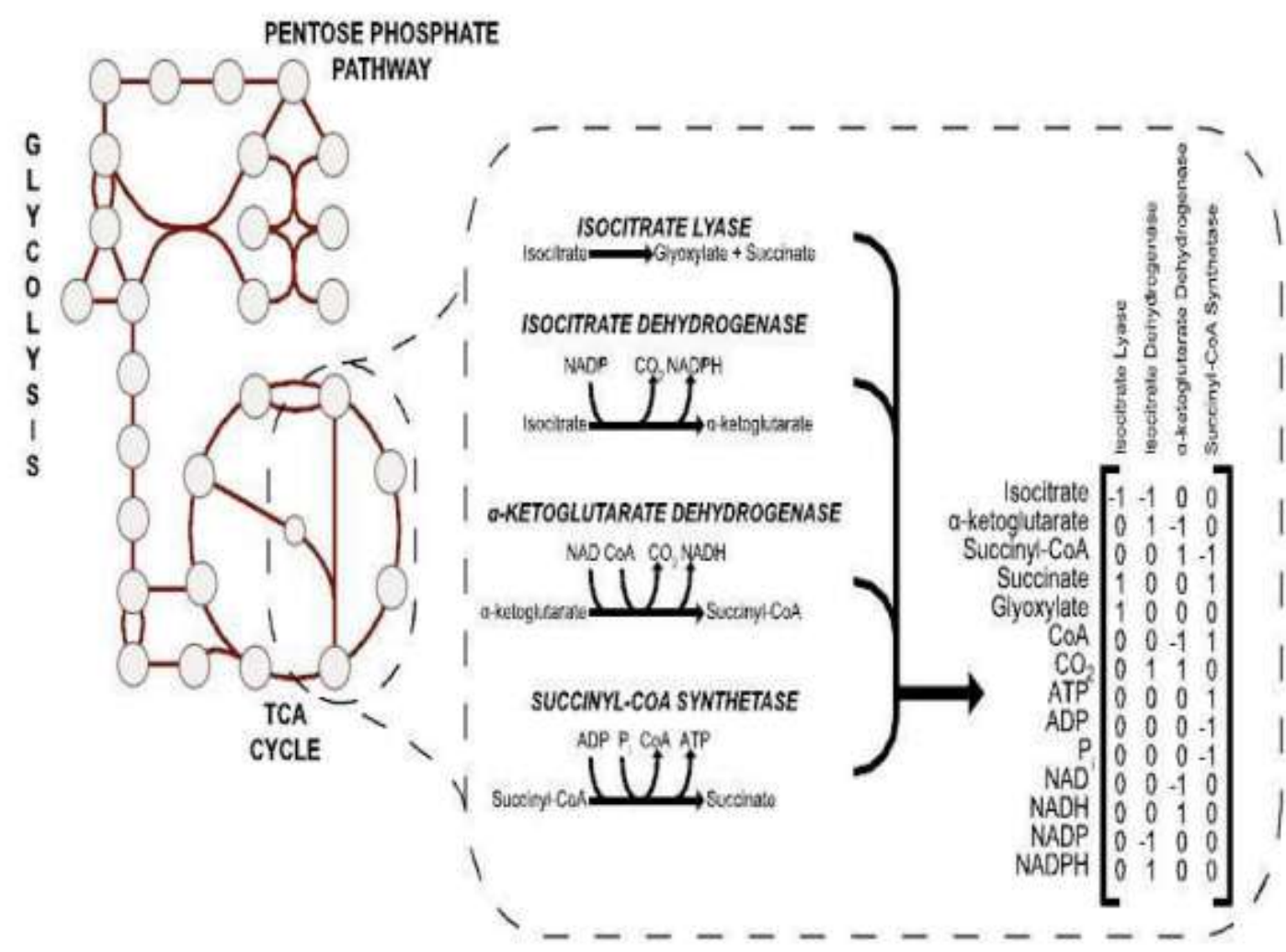

Gambar 5. Hasil formulasi matric stoichiometric pada E.coli ( Hefzi et al, 2013)

Jika pada setiap level genomic, level seluler dan pathway telah diketahui maka reaksi metabolisme yang kompleks dapat dikendalikan dan atau diarahkan untuk mendapatkan hasil yang diinginkan. (Oberhardt et al, 2009 ).

\section{APLIKASI}

Berbagai aplikasi dapat dikembangkan berdasarkan pemahaman pada regulatory 
network dan rekonstruksi network metabolism. Beberapa contoh aplikasi antara lain adalah metabolic engineering, penemuan biologi, dan prediksi dan evaluasi suatu fenotipe (gambar 5)

\section{Metabolic engineering}

Digunakan untuk melengkapi dan menyempurnakan teknik rekayasa genetika. Selama ini rekayasa genetika telah menghasilkan produk yang bermanfaat baik di bidang pangan maupun kesehatan (Windass et al, 1980). Meskipun begitu teknik ini belum dapat mengidentifikasi terjadinya perubahan yang terjadi secara spesifik pada produk yang dihasilkan. Metabolic engineering memungkinkan terjadinya perbaikan karena proses pada level genom scale sudah dapat diprediksi sehingga sangat potensial pengembangan produk melalui manipulasi (Bailey et al, 1990). Produksi likopen dalam Escherichia coli merupakan salah satu contoh aplikasi menggunakan metabolic engineering. Licopen dapat dihasilkan oleh E.coli dengan memasukkan gen heterolog ke dalam jaringan metabolik ( Hefzi et al, 2013). Secara komputasi dapat direkayasa posisi knock out gen tunggal untuk menghasilkan lycopene pada E. coli. Rekayasa dilakukan dengan tetap mempertahankan strain induk yang sudah direkayasa dengan laju pertumbuhan yang tetap terjaga sehingga hasil licopene dapat diatur.

\section{Penemuan biologi}

Proses rekonstruksi umumnya menggunakan hipotesis. Terjadinya inkonsistensi antara hipotesis dan hasil penemuan membuat diperlukannya analisis data fisiologis untuk menjelaskan perbedaan tersebut. Mekanisme ini tidak jarang menghasilkan suatu penemuan baru yang berkaitan dengan jalur metabolisme suatu organisme (Reed et al, 2006). Dengan membandingkan jalur metabolism organisme lain maka jalur metabolisme suatu organisme dapat diidentifikasi. Salah satu contohnya adalah rancangan percobaan untuk mengetahui open reading frame (ORF) yang mengkode enzim yang dibutuhkan pada suatu reaksi. Pada E.coli diketahui bahwa enzim tidak dapat bekerja pada D - malat sementara hasil eksperimen menunjukkan enzim dapat bekerja pada D- malat. Model alogaritma dapat mengidentifikasi jenis reaksi yang kurang sehingga dapat diketahui ORF yang tepat untuk bekerjanya enzim pada suatu reaksi.(Reed et al, 2006)

\section{Prediksi dan evaluasi fenotipe}

Pada umumnya Pada umumnya metabolic genome scale digunakan untuk memprediksi fenotipe yang dihasilkan dalam berbagai kondisi. Proses ini berjalan siklik 
sehingga jika terjadi kegagalan pada satu tahap maka dapat diketahui dengan menganalisa penyebab kegagalan tersebut. Dilakukan modifikasi berulang untuk memperbaiki formula dengan cara menggabungkan beberapa data yang telah diketahui misalnya gen, metabolite dan pereaksi (Kummel et al, 2006)

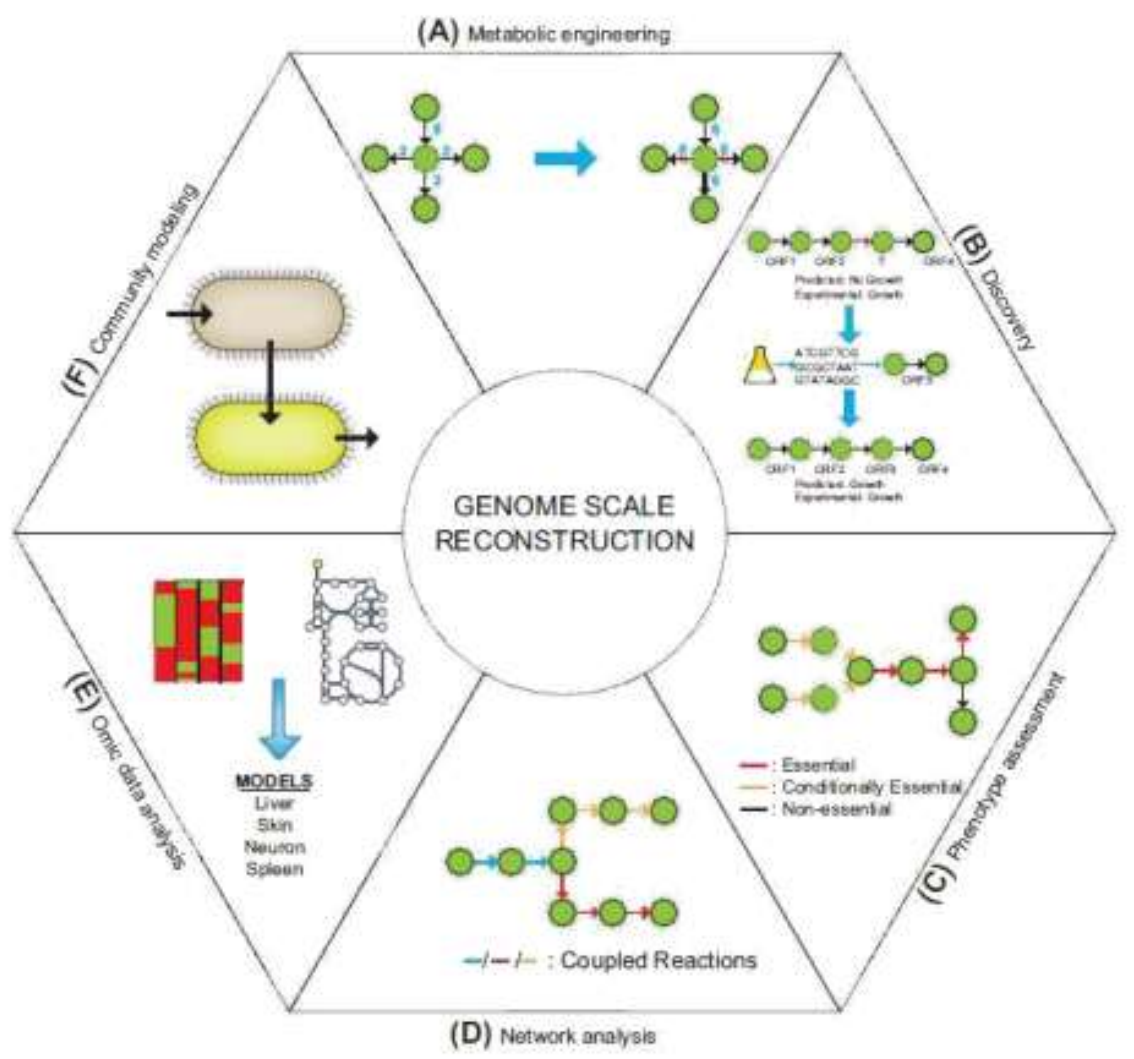

Gambar 6. Aplikasi genome scale metabolic reconstruction (Hefzi et al, 2013)

\section{KESIMPULAN}

Metabolisme adalah proses terpenting bagi makhluk hidup, namun baru sebagian metabolic network yang dapat terpetakan. Rekonstruksi metabolic network pada E.coli merupakan tahap awal untuk mengembangkan pemodelan yang lebih holistic khususnya untuk mengembangkan model yang dapat menggabungkan antara regulasi gen, metabolisme dan enzim sehingga dapat menghasilkan reaksi yang lebih prediktif yang dapat dimanfaatkan bagi kesejahteraan umat manusia.

\section{DAFTAR PUSTAKA}

Adam, et al. 2002. Biosynthesis of terpenes: studies on 1-hydroxy-2-methyl-2 butenyl 4 
diphosphat reductase. Proceeding National Academic Science USA.

Bailey et al. 1990. Strategies and challenges in metabolic engineering. Annual New York Academic Science

Costa et al. 2008. Complex networks: The key to systems biology. Instituto de Física de São Carlos, Universidade de São Paulo, São Carlos, SP, Brazil. Jurnal Genetics and Molecular Biology

Hefzi H et al .2013. Reconstruction of Genome Scale Metabolic Network. Hand Book of System Biology: Concept and Insight. First Edition. Elsevier

Hein et al. 2013. Proteomic Analysis of Cellular Systems. Hand Book of System Biology: Concept and Insight. First Edition. Elsevier

Karp G. 2010. Cell and Molecular Biology :Concept and Experiment. John Wiley \& Sons, Inc 111 River Street, Hoboken, NJ 07030-5774

Kusnadi. 2009. Metabolisme. Fakultas Pendidikan Matematika dan Ilmu Pengetahuan Alam. Universitas Pendidikan Indonesia

Reed et al. 2006. System approach to refining genome annotation. Proceeding National Academic Science USA

Peter I.S \& Davidson E.H. 2013. Transcriptional Network Logic: The System Biology of Development. Hand Book of System Biology: Concept and Insight. First Edition. Elsevier

Suarsana. 2009. Regulasi Metabolisme dan Sistem Organ. Laboratorium Biokimia Veteriner Fakultas Kedokteran Hewan Universitas Udayana

Wagner, A. 2012. The role of Robustness in Phenotypic Adaptation and Innovation. Institute of Evolutionary Biology and Environmental Studies, University of Zurich, Jurnal of The Royal Society

Windass et al. 1980. Improved conversion of methanol to single cell protein by methylophilus methylotropus. Jurnal of Nature

Unduhan :

Harvard Medical School (2010)

https://sysbio.med.harvard.edu/

http://manet.illinois.edu/pathways 